\title{
Konseptual Motivasi Kerja di Lembaga Pendidikan Islam
}

Siti Nursyamsiyah

Universitas Muhammadiyah Jember

Email : sitinursyamsiyah@unmuhjember.ac.id

\section{Submission}

Track:

Received:

3 februari 2020

Final Revision:

15 Maret 2020

Available online:

25 Maret 2020

Corresponding

Author:

Name \& E-mail Address

Siti Nursyamsiyah

sitinursyamsiyah@unmuhjember.ac.id

\begin{abstract}
The concept of motivation Maslow's ideas "'" self-actualization is the person's motivation to transform perception of self into reality ". Motivation is the most basic factor in educational institutions to mobilize human resources potential to grow enthusiasm in working with organizational objectives. The second factor is the leader as a leader able to mobilize human resources. Sensitivity of a leader is expected to understand the nature and human needs. Hierarchy of human needs is expected to be another consideration in motivating staff, teachers (cleric) or employees. Five things humans need to note are: physiological, safety, social, esteem and self-actualization needs. If a leader promoting the values of humanity in motivating subordinates,
\end{abstract}

Keywords: Conceptual, Motivation, Work

\begin{abstract}
Abstrak
Konsep ide motivasi Maslow "“"self actualization is the person's motivation to transform perception of self into reality". Motivasi merupakan faktor paling dasar dalam lembaga pendidikan untuk menggerakkan potensi sumber daya manusia untuk menumbuhkan antusiasme dalam bekerja dengan tujuan organisasi. Faktor kedua adalah pemimpin sebagai leader yang mampu menggerakkan sumber daya manusia. Kepekaan pemimpin sangat diharapkan untuk memahami sifat-sifat dan kebutuhan manusia. Hirarki kebutuhan manusia diharapkan bisa menjadi pertimbangan lain dalam memotivasi staf, guru (ustadz) atau karyawan. Lima hal kebutuhan manusia yang perlu diperhatikan yaitu: fisiologis, keamanan, sosial, penghargaan dan kebutuhan aktualisasi diri. Jika seorang pemimpin mengedepankan nilai-nilai kemanusiaan dalam memotivasi bawahannya, maka produktivitas dan kesuksesan bisa dapat terwujud dalam lembaga atau instansi yang dipimpin
\end{abstract}

Kata Kunci: Konseptual, Motivasi, Kerja

\section{PENDAHULUAN}

Motivasi dapat dipandang sebagai bagian integral dari administrasi kepegawaian dalam rangka proses pembinaan, pengembangan dan pengarahan tenaga kerja dalam suatu organisasi atau dalam suatu lembaga pesantren. Karena manusia factor yang menentukan kelancaran administrasi, factor motivasi merupakan pendukung yang memerlukan perhatian sungguh-sungguh di lingkungan lembaga pesantren atau lembaga pendidikan lainnya.

Dengan demikian, maka motivasi dapat ditempatkan paling dasar dalam manajemen. Selain itu, mengerahkan potensi sumber daya manusia di lingkungan pesantren melalui menumbuhkan dan menghidupkan serta menimbulkan antusiasme secara bersama dalam menjalankan tugas-tugas individual maupun perkelompok. Dalam hubungan pekerjaan yang dibebankan pada seseorang, maka motivasi 
memiliki peran sebagai pendorong ghiroh yang kuat untuk melakukan pekerjaan seseuai dengan ketentuan yang berlaku di lingkungan pesantren.

Berangkat dari pemikiran itu, maka dalam tulisan ini akan mencoba membahas persoalanpersoalan seputar motivasi tersebut secara singkat tetapi padat, agar mudah dimengerti dan difahami. Lebih-lebih para praktisi, termasuk guru yang mengajar di lembaga pendidikan pesantren, pemimpin seharusnya memiliki kepentingan besar tentang persoalan motivasi ini dalam rangka menjalankan tugas keseharian.

\section{PEMBAHASAN}

\section{Konsep Motivasi}

Pada dasarnya konsep motivasi merupakan bentuk keinginan yang timbul dari diri seseorang tanpa adanya pakasaan dalam melakukan pekerjaan (Mitchell, 1982:81). Kata motivasi memiliki sifat individual dalam artian menurut bahasa manusia termotivasi dari berbagai macam aspek. Semisal motivasi ini dilakukan dengan sengaja bukan datang tiba-tiba, aspek yang terpenting dari motivasi adalah bentuk penggerakan perilaku manusia menuju kea rah yang tertentu yang diinginkan.

Motivasi berasal dari kata latin "movere" yang berarti dorongan atau daya penggerak (S.P Hasibuan, 2003).

Motivasi sering diartikan dalam kamus Besar yaitu termasuk bentuk dorongan yang muncul pada diri manusia secara sadar atau tidak sadar untuk melakukan suatu pekerjaan yang dituju, di samping itu, motivasi diartikan sebagai bentuk usaha yang dilakukan seseorang ataupun kelompok untuk melakukan pekerjaan yang ingin dicapai (Kamus Besar Bahasa Indonesia, 2001:756).

Menurut (Robbins, 2001) motivasi didefinisikan sebagai upaya seseorang untuk mencapai tujuan lembaga, dalam hal ini kemampuan seseorang dikondisikan untuk mememnuhi kebutuhannya. Secara umum, motivasi berkaitan dengan upaya seseorang untuk mencapai tujuan organisasi yang menggambarkan terhadap minat dan perilaku yang berhungan dengan pekerjaan. Ketiga unsur kunci dalam definisi kita adalah upaya, tujuan organisasi, dan kebutuhan. Berbeda halnya dengan yang ditawarkan oleh Mc. Dougell motivasi merupakan kondisi Psikologis yang diwariskan untuk memperoleh dan memperhatikan obyek serta melakukan cara tertentu terkait obyek tersebut (Mc.Dougell).

Konsep motivasi menurut Zainun (1979:13), adalah merupakan tingkah laku manusia dalam kegiatan dengan tujuan untuk mencapai tujuan dengan cara adanya beberapa factor yang terdapat di dalam lembaga atau organisasi.

Hal senada juga diungkapkan oleh Widjaja (Widjaja, A, 1986), motivasi adalah yang membedakan antara keinginan seseorang untuk melakukan pekerjaan atau justru sebaliknya. Motivasi termasuk kemauan keras untuk melakukan pekerjaan dengan tujuan mencapai tujuan tertentu yang telah ditetapkan oleh lembaga maupun organisasi. Lebih lanjut dikatakan, motivasi dapat diartikan sebagai dorongan mental perorangan atau kelompok dalam menanggapi suatu peristiwa dalam masyarakat. Atau, sebagai suatu proses untuk mencoba mempengaruhi orang-orang yang dipimpinnya agar mau melaksanakan pekerjaan yang diinginkan sesuai dengan tujuan tertentu yang telah ditetapkan lebih dahulu.

Sedangkan motivasi menurut (Rahim, Abdul dan Irmin, 2004) adalah kesadaran berfikir tentang 
pentingnya mengolah potensi yang dimiliki oleh setiap orang. Dengan kata lain, orang yang memiliki potensi tetapi tidak memiliki motivasi yang tinggi, sama dengan sebilah pedang tajam tetapi tidak ada pemiliknya.

Dari konsep-konsep tersebut, dipertegaskan motivasi termasuk fakta yang menunjukkan kondisi manusia termasuk di dalamnya kejiwaan, sikap maupun mental yang sedang menghadapi yang menantang dalam situasi tertentu dan menimbulkan rangsangan. Secara sederhana, motivasi dapat pula dimaknai sebagai dorongan untuk melakukan sesuatu, dorongan itu bisa datang baik dari dalam (motivasi internal) atau dari luar (motivasi eksternal). Dalam realitanya, dua jenis motivasi ini hanya bisa dibedakan namun sulit bahkan tidak bisa dipisahkan. Sebab keduanya seringkali saling mempengaruhi. Hal ini bisa dijumpai ketika motivasi internal seseorang semakin meningkat ketika lingkungan sekitar semakin menggugah kesadarannya untuk berbuat, bertindak ataupun bertugas lebih dari apa yang dilakukannya selama ini.

Dalam literatur keislaman, ada ungkapan mengatakan "ibda' binafsika" atau mulailah dari dirimu sendiri. Dalam rujukan lain ada ungkapan "alI'timadu ala al nafsi asasu al-najahi" (bersandar pada diri sendiri/termasuk motivasi diri adalah landasan kesuksesan). Kedua pernyataan di atas menunjukkan bahwa betapapun besarnya motivasi ataupun dorongan eksternal tidak akan bayak berpengaruh dalam peningkatan motivasi seseorang jika tanpa dibarengi oleh hasrat diri untuk mau melakukan sesuatu (motivasi internal).

Sebagai contoh, sorang ustadz, karyawan ataupun tenga pendidik dalam sebuah pesantren. Ia diharapkan bisa menjadi ustadz yang professional dan ideal. Karena itu, kyai sebagai pemimpin di pesantren (leader) ingin merealisasikan itu dalam rangka meningkatkan SDM pesantren. Apapun yang dilakukan atau disarankan kyai tidak lebih ibarat "radio rusak" yang hanya berbunyi namun tidak didengar, diperhatikan apalagi diindahkan oleh staf karyawan atau ustadz itu tadi.

Contoh lainnya adalah ketika kepala sekolah menyuruh pemasangan tulisan yang impulsif dan motivatif dalam ruang kelas yang selanjutnya bisa dipertimbangkan oleh guru. Contohnya, di dinding kelas terpampang indah tulisan/khot berbunyi “tarju al-najaata walam tasluk masalikaha, inna al-safinata lam tajri ala al-yahasi" (engkau ingin selamat/sukses tetapi tidak menempuh jalannya, ingat! Perahu tidak akan pernah berlayar ditempat yang tandus). Tulisan itupun tidak lebih dari sekedar "dekoras?" yang lebih "memuaskan mata" dari pada "mengena di hati" para guru atau karyawan yang lainnya. Itulah sedikit gambaran tentang hubungan antara motivasi internal dan eksternal.

\section{Pendekatan Motivasi Kerja}

Guru mengajar di pesantren dengan tujuan pengabdian lillahita'ala untuk mengamalkan ilmu. Upah mengajar bukanlan tujuan guru di pesantren, ikhlas sebagai landasan guru dalam mengajar. Sehingga motivasi guru dalam bekerja merupakan hanya semata-mata meraih pahala. Inilah realita yang terjadi di semua pesantren. Beda halnya dengan lembaga lainnya upah merupakan orientasi dalam bekerja. Sebagaimana yang dikemukan oleh Katz dan Kahn tentang motivasi dalam bukunya (Hanson, n.d.) adalah menggunakan hedonisme yaitu: (1), Prilaku diarahkan untuk memenuhi kenikmatan dan kenyaman; (2) Prilaku diarahkan untuk menghindari ketidak nikmatan dan ketidak nyamanan. Dengan menggunakan pendekatan tersebut maka dapat 
mengetahui aspek-aspek guru merasa puas dan guru tidak merasa puas di pesantren yang dapat dikaitkan dengan teori di bawah ini. Adapun aspek-aspek guru merasa puas menurut (Galloway, 1985) di antaranya:

1. Ketika guru berkomunikasi dengan murid

2. Berkomunikasi dengan guru yang lain.

3. Guru memiliki kebebasan dalam menerapkan metode pengajaran.

4. Jadwal yang telah disusun / Program yang telah ditetapkan.

5. Guru memiliki kebebasan memilih materi yang akan diajarkan.

6. Berapa banyak jam mengajar guru dalam waktu setiap minggu.

7. Cara guru berkomunikasi dengan staf senior di lingkungan pesantren.

8. Seberapa banyak prestasi siswa di kelas.

9. Pengelompokan guru untuk menentukan jadwal mengajar pada kelas khusus.

10. Prilaku umum siswa di kelasnya.

Sedangkan aspek-aspek ketidakpuasan guru diantaranya:

1. Metode dalam kegiatan mempromosikan guru.

2. Respon masyarakat dalam masalah pendidikan.

3. Terkadang guru belum memiliki kesempatan mengikuti pendidikan tambahan yang dilakukan di lingkungan maupun di luar sekolah.

4. Ketidak jelasan pengelolaan waktu di lingkungan sekolah.

5. Permasalahan gaji belum ada transparansi.

6. Ketidak jelasan status guru di lingkungan masyarakat.

7. Pemberian waktu yang cukup pendek untuk penyiapan soal maupun mengoreksi hasilnya.

8. Staf yang ada untuk membantu pelayanan belum jelas
9. Ketidak jelasan jumlah jam mengajar guru di luar mengajar setiap minggu.

10. Fasilitas sebagai sarana untuk rekreasi belum jelas. (Galloway, 1985).

Ada beberapa pendekatan motivasi yang ditawarkan oleh (Widjaja, A, 1986:17) antara lain:

\section{Tradisional approach}

Menurut pendekatan tradisional mengatakan bahwasannya orang sebenarnya tidak suka untuk bekerja, mereka bekerja karena sebuah kebutuhan yaitu untuk mendapatkan uang. Dan mereka mau bekerja karenan adanya ketakutan akan kehilangan pekerjaan. Bentuk motivasi pada pendekatan tradisional ini menekankan pada bentuk reward ataupun otoritas.

Pendekatan tradisional, menurut Widjaja menyamakan dengan teori Douglas Mc Gregor yang terkenal dengan teori $\mathrm{X}$ disebut pandangan tradisional yang intinya adalah:

(a) Manusia pada dasarnya malas dan akan menghindari pekerjaan jika dapat.

(b) Pada dasarnya manusia bersifat diperintah, diawasi, serta patut diberi dorongan melakukan sesuatu dan memiliki rasa takut meninggalkannya dan rasa ini timbul pada jiwa mereka sebagai harapan instansi atau lembaga dalam hal ini bisa sekolah atau perusahaan.

(c) Mayoritas dalam lembaga manusia lebih cenderung pada perintah atasan, ingin menghindari dari kewajiban tugas, terkadang ada keinginan namun sebenarnya manusian menginginkan rasa aman dan keputusan yang jelas.

\section{Pendekatan Internalized Motivation}

Menurut pandangan ini, menjelaskan bahwasannya manusia diberi motivasi merupakan kesempatan untuk meraih kepuasan tertentu serta 
memiliki kesempatan melakukan pekerjaannya, jika motivasi dating dari hati nurani manusia sendiri maka mereka dengan sengang hati melakukan pekerjaannya tanpa adanya paksaan. Menurut Widjaja, salah satu teorinya Douglas dalam pendekatan internalization yang menggunakan teori Y intinya adalah:

(a) Manusia pada dasarnya aktif, rajin, dapat merumuskan tujuan-tujuan untuk mengejar citacita.

(b) Manusia kesehariannya disibukkan dengan pekerjaan untuk mencapai kepuasan, prestasi serta mampu menganalisa dan menghadapi masalah yag datang.

(c) Mereka dirangsang dengan tujuan ganda yaitu tujuan pribadi dan kelompok.

(d) Manusia mempergunakan pikiran, mampu bertanggung jawab serta mau berja dengan giat dan kemandirian dapat dilihat dalam pekerjaan.

(e) Manusia dapat menutupi kebutuhan sendiri dengan tidak menggantung pada orang lain.

(f) Orang telah mengerti tentang daya guna, hasil guna, dan tepat guna atas pekerjaannya.

(g) Orang dapat menilai atas prestasi yang telah diraih serta selalu aktif, keratif berkreasi untuk perkembangan.

(h) Orang telah mengapresiasi pekerjaan dan waktu.

(i) Orang selalu muncul dan berkembang untuk kemajuan.

\section{Pendekatan Human Relation}

Pendekatan buman relation menggambarkan bahwasannya orang mau bekerja jika memiliki rasa aman, tempat yang mendukung, pemimpin jujur dan demokratis, melakukan pekerjaan dengan senang dan semangat tinggi. Primary needs yang dipuaskan menurut buman relation ini adalah security dan social needs, sedang primary rewards yang diharapkan ialah
"Around the job or extrinsic, including peer approval, praise from boss, comfortable working codition. Also fair pay, security, and fringe benefit'. Pendekatan buman relation ini mengatakan bahwa adanya kepuasan itulah yang menimbulkan produktivitas.

Dengan memahami pendekatan tersebut di atas, sampailah pada kita kepada suatu kesimpulan bahwa sebagai seorang pemimpin harus mampu menganalisa dan memahami sifat-sifat kebutuhan para bawahan yang merupakan motivator bagi tingkah lakunya, agar kita mengetahui bagaimana memotivasi mereka untuk melakukan pekerjaan yang diserahkan kepadanya dengan sebaik-baiknya. Untuk itu perlu dipahami terlebih dahulu jenis-jenis kebutuhan yang merupakan faktor penggerak tingkah laku manusia. Berkaitan dengan cara memahami orang lain ini, maka direktur General Electris Company, termasuk salah satu perusahaan listrik paling besar di dunia yang bernama O.D. Young, seperti dilansirkan oleh (Carnegie, 1979: 25), mengatakan bahwa ketika seseorang mampu menempatkan dirinya serta tahu apa yang dipikirkan orang lain, maka tidak perlu khawatirkan masa depannya. Artinya, seorang pimpinan atau kyai sebagai pemimpin di pesantren mengetahui watak dan karakteristik ustdaz atau ustadzah yang mengajar, karyawan atau bawahannya, maka dalam menciptakan semangat atau motivasi kerja terhadap mereka, akan lebih manusiawi. Jika seorang pemimpin mengedepankan nilai-nilai kemanusiaan dalam memotivasi bawahannya, maka produktivitas dan kesuksesan bisa dapat terwujud dalam lembaga atau instansi yang ia pimpin.

\section{Langkah-Langkah dalam Memotivasi}

Kebutuhan-kebutuhan yang berupa motivasi ustadz, guru atau pegawai dalam pekerjaan, 
sebenarnya dapat pula dipenuhi dengan berbagai jalan. Menurut W. Clay Hammer dalam memotivasi guru sebagai tenaga pendidik dengan menggunakan pembentukan perilaku, diantaranya:

1. Tidak membiasakan memberikan penghargaan dalam bentuk yang sama pada semua orang.

2. Perlu memahami bahwa kritikan orang lain dapat memberikan perubahan pada perilaku.

3. Menginformasikan hal-hal yang perlu dilakukan pada karyawan.

4. Jika ada perilaku yang salah perslu secepatnya diberitahu.

5. Hendaknya menegur dan memberi punishment tidak di depan karyan lainnya.

6. Berlaku adil. (Hanson, n.d.).

Di bawah ini diutarakan beberapa kegiatan yang mampu membangkitkan motivasi dan ghiroh dalam bekerja. Kegiatan tersebut antara lain adalah:

\section{Orientation}

Dalam lembaga pesantren perlu memperhatikan kegiata-kegiatan yang ada di dalamnya. Berkaitan dengan motivasi orientasi pada perlu ada keseimbangan yang dilakukan lembaga. Orientasi perlu diarahkan pada dua kubu yaitu orientasi pekerjaan dan pegawai. Dalam hubungan dengan kedua macam orientasi itu dijumpai dua aliran yang masing-masing menekankan kepada salah satu orientasi tersebut. Yang menekankan kepada manusia disebut aliran organistik atau aliran tingkah laku dan yang menekankan kepada pekerjaan disebut aliran mekanistik atau formil.

\section{Supervision}

Sebagai supervisi hendaknya tidak terlalu ketat dan memberikan keleluasaan pada bawahan agar merekan mereka leluasa dan mampu memprakarsai dalam melakukan tugas-tugasnya. Dengan alasan karyawan memiliki rangsangan yang sangat kuat dari hasil pekerjaannya dari pada mereka bekerja atas perintah dan paksaan. Supervisi di lingkungan pesantren yang terlalu kaku akan mematikan kretivitas sehingga lembaga sulit berkembang.

\section{Partisipation}

Setiap pemimpin pasti memiliki gaya tersendiri dalam setiap lembaga, pemimpin yang sering memberikan banyak kesempatan pada bawahannya untuk berpartisipasi dalam segala hal maka disebut pemimpin demokratis. Namun seoran pemimpin yang menrapkan gaya demokratis perlu ada kewaspadaan terhadap gejala negative seperti tingkah laku yang menyimpang dan ini tidak sedikitpun mengurangi peranan pemimpin. Seseorang akan merasa dirinya cukup penting dan merasa sebagai bagian dari keseluruhan bila mana diikutsertakan dalam berbagai usaha bersama dalam organisasi. Pemberian kesempatan dapat menimbulkan dan meningkatkan rasa percaya diri sendiri dan merasa memilikinya.

\section{Komunikasi}

Organisasi dalam hal ini sekolah yang merangsang guru dan karyawannya untuk bekerja giat adalah suatu sekolah yang membuka jalur-jalur dan menjamin lancarnya arus komunikasi ke semua arah. Dengan komunikasi, guru atau karyawan dapat mengetahui kebijaksanaan-kebijaksanaan kepala sekolah serta peristiwa-peristiwa yang terjadi di sekolah dengan segala akibat dan permasalahannya. Orang yang berada dalam posisi mengetahui, jauh lebih semangat kerjanya daripada orang yang tidak mengetahui atau buta mengenai berbagai hal yang seharusnya diketahuinya.

5. Delegation

Dalam hal ini, berkaitan dengan asas desentralisasi dan decosentrasi dalam sebuah 
organisasi, pimpinan organisasi memberikan wewenan yang sepada terhadap bawahannya. Pemberian wewenang ini disertai dengan pengawasan dan kewaspadaan. Oleh karena itu, pendelegasian ini, sebagai manajer atau kepala sekolah harus meyakinkan bahwa guru atau karyawan yang didelegasikan itu mampu dan dipercaya dapat menjalankan tugas-tugas itu dengan baik.

\section{Competition}

Organisasi sekolah maupun organisasi lainnya, perlu mengembangkan kompetisi yang sehat agar ada perbaikan pada individu maupun posisi. Karena denga melakukan kompetisi yang sehat akan menciptakan iklim yang dinamis menuju kemajuan. Namun sebaliknya kompetisi yang tidak sehat justru akan menimbulkan ketegangan-ketegangan dan perasaan rendah diri dan putus asa pada pihak-pihak tertentu.

\section{Integrasi}

Tujuan dan kepentingan pribadi maupun kepentingan sekelompok orang, dalam sebuah organisasi baik itu mengarah pada tujuan social ataupun tujuan secara formal perlu diintegrasikan dalam tujuan akhir organisasi sekolah. Sehingga muncul keyakinan dan kepuasan semua elemen organisasi dapat terpenuhi secara adil.

\section{Cross motivation}

Maksud dari cross motivation yaitu motivasi bukan hanya dari kepala sekolah kepada bawahannya, namun sebagai bawahan perlu memberikan motivasi pada atasan dengan cara yang wajar. Karena untuk mewujdkan usaha kerjasama yang serasi dan saling menguntungkan untuk semua pihak maka cross motivation ini perlu dikembangkan.(Zainun, 2003).

Dari delapan langkah motivasi tersebut di atas, ada sebuah teori yang bernama teori kadar motivasi (the content theories of motivation), berusaha untuk menerangkan apa yang menyebabkan manusia mau bekerja. Teori ini berusaha untuk mengadakan identifikasi kebutuhan-kebutuhan manusia dan bagaimana kebutuhan-kebutuhan tersebut disusun berdasarkan urutan-urutan prioritas, di samping itu juga memperhatikan tentang jenis-jenis intensif dan tujuan-tujuan yang ingin dicapai oleh manusia agar supaya memperoleh kepuasan diri.

Pertama-pertama urutan prioritas kebutuhan tersebut jatuh pada uang. Namun dalam perkembangannya, urutan kebutuhan itu jatuh pada kondisi tempat bekerja, security dan supervisi yang demokratis (golongan buman relation). Kemudian timbulah anggapan baru, yang mengatakan bahwa ada tingkat kebutuhan yang lebih tinggi yang disebutnya responsibility, recognasition, achievement (Herzberg); growth dan personal development (Aldefer). Abraham Maslow (dalam Widjaja, 1986:24), salah satu tokoh yang menyusun hirarki motif kebutuhan manusia menyebutkan uratan-urutannya antara lain:

1. Basic need, ini adalah kebutuhan yang paling dasar dan umumnya merupakan hal-hal yang bersifat tidak dipelajari. Seperti kebutuhan akan makan, minum, seks dan sebagainya. Untuk melakukan hal ini, orang mau melakukan pekerjaan untuk memperoleh uang hal inilah yang menjadi motivasinya.

2. Safety atau security need adalah dalam sebuah organisasi kebutuhan rasa aman serta kebebasan dari ancaman merupakan bagian dalam organisasi untuk mendapatkan keselamatan pekerjaan. Berikut ini ada 2 bentuk kebutuhan manusia dalam organisasi. Pertama, Manusia membutuhkan keamanan jiwa di tempat pekerjaan karena setiap manusia membutuhkan keamanan dan keselamatan jiwa di mana dan kapan saja ia 
berada. Kedua, kebutuhan akan keamanan harta di tempat pekerjaan pada jam kerja.

3. Love atau belonging needs, mempunyai hubungan dengan hal-hal yang menyangkut kebutuhan efeksi dan afiliasi. Artinya, dalam kehidupan ini membutuhkan rasa untuk disayang dan menyayang antar sesame dan kebutuhan untuk berkumpul dengan orang lain.

4. Esteem needs atau kebutuhan akan penghargaan. Menurut Maslow, bahwa ini merupakan tingkat kebutuhan manusia tertinggi (seperti kebutuhan akan kekuasaan, prestasi dan status. Lebih lanjut dikatakan, dalam esteem needs ini terdapat apa yang disebutnya dengan self esteem dan esteem from others.

Bersamaan dengan kebutuhan-kebutuhan tersebut, Hasibuan(S.P Hasibuan, 2001), juga menambahkan satu kebutuhan lagi adalah self actualization. Self actualization adalan kebutuhan berekpresi dan beraktualisasi menyesuaikan dengan kemampuan dan keterampilan yang dimiliki secara optimal untuk mencapai prestasi kerja yang memuaskan. Menurutnya, potensi yang dimiliki seseorang perlu diaktulaisasikan secara penuh. Atau dengan kata lain, menunjukkan titik kulminasi dari kebutuhan-kebutuhan tingkat bawah, menengah dan tingkat tinggi dari manusia, di mana manusia mempunyai keinginan untuk menunjukkan kemampuan mewujudkan dirinya. Perwujudan diri ini ditampilkan dari prestasi dan kemampuan melaksanakan konsep-konsep, ide-ide di dalam kenyataan, seperti apa yang diistilahkan oleh (Maslow, 1994), "self actualization is the person's motivation to transform perception of self into reality".

Hirarki kebutuhan seperti yang ditawarkan oleh Maslow, dapat digambarkan sebagai berikut:

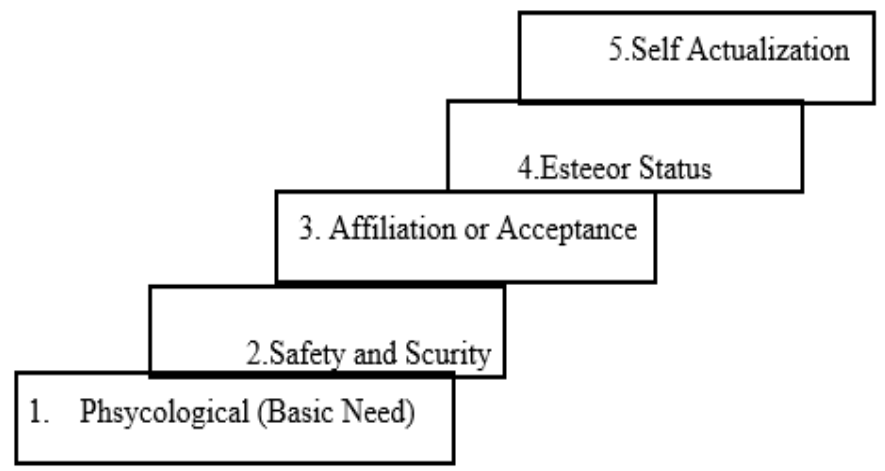

Selain langkah-langkah yang telah ditawarkan tersebut diatas, (Handoko, 1987:155), juga menawarkan cara untuk meningkatkan prestasi kerja melalui motivasi dan kepuasan kerja yang hamper sama dengan lainnya yaitu cara cara kompensasi. Karena kompensasi merupakan reward yang diberikan pada guru sesuai pekerjaan yang dikerjakannya, sehingga para karyawan merasa terpuaskan dan termotivasi untuk mencapai sasaran organisasi sekolah. Begitu pula sebaliknya, jika para guru atau karyawan memandang kompensasi tidak memadai atau tidak setimpal, maka motivasi, kepuasan dan prestasi kerja bisa menurun secara drastic. Lebih lanjut Handoko mengatakan, programprogram komensasi sangat perlu bagi sekolah maupun sebuah perusahaan, karena mencerminkan upaya organisasi untuk mempertahankan sumberdaya manusia. Bahkan bila kompensasi dan pengagajian tidak diadministrasikan secara tepat, maka sekolah atau perusahaan akan kehilangan guru atau karyawan yang berkualitas, bahkan konsekuensinya akan mengeluarkan biaya yang besar untuk menarik, menyeleksi, melatih dan mengembangkan tenaga baru sebagai penggantinya.

Di samping langkah-langkah motivasi di atas, pertimbangan lain yang harus diperhatikan dalam menentukan langkah apa yang efektif untuk 
memotivasi bawahan adalah tingkat kematangan bawahan (maturity of saff). Mengenai tingkat kematangan bawahan terdapat dua dimensi yaitu:

1. Kematangan kerja (job maturity)

2. Kematangan jiwa (psychological maturity)(Sutarto, 2011).

Jika kematangan kerja berhubungan dengan ability atau kemampuan bawahan yang akan dimotivasi, maka yang kedua ini berkaitan dengan kesediaan atau kemauan (willingness \& readiness) seseorang untuk bekerja sehingga perlu untuk dimotivasi atau tidak, cara yang baik untuk memotivasi dan lain sebagainya.

Selanjutnya kedua hal di atas dibagi menjadi empat bagian:

1. Kode MI merupakan tingkat kematangan rendah yang memiliki karakteristik: tidak mampu, tidak mau atau tidak mantap.

2. Kode M2 merupakan tingkat rendah menuju tingkat kematangan madya yang memiliki karakteristik: tidak mampu tetapi mau tau yakin.

3. Kode M3 merupakan tingkat kematangan madya menuju tingkat kematangan tinggi yang memiliki karakteristik: mampu tetapi tidak mau, tidak yakin atau tidak mantap.

4. Kode M4 merupakan tingkat kematanagn tinggi yang memiliki karakteristik: di smaping mampu, ia juga mau, mantap dan yakin.

Keempat tingkat kematangan di atas perlu dipahami oleh setiap orang khususnya atasan dalam memotivasi bawahannya, sebab perbedaan kematangan kerja dan kematangan psikologis masing-masing individu yang mesti ditemukan menuntut perbedaan cara dalam mendekati mereka (memotivasi) dalam rangka menyiapkan sumber daya manusia yang handal.

Terkait dengan keempat hal di atas bisa dielaborasikan lagi menjadi:

1. Bawahan yang kematangan kerja dan psikologisnya rendah harus banyak dimotivasi, di dorong ataupun diberi saransaran tertentu yang terkait dengan pekerjaannya. Gaya ini disebut dengan "telling".

2. Bawahan yang kematangan kerja rendah tetapi kemauan dan semangat yang tinggi (dari pada rajin tetapi banyak salahnya), maka perlu diberikan pengarahanpengarahan, pendidikan yang bisa meningkatkan kemampuannya, sehingga terjadi keseimbangan antara kemauan dan kecakapannya tadi. Cara ini dikenal dengan "selling". Dalam konteks organisasi dan ataupun lembaga pendidikan, teramat banyak staf, karyawan ataupun guru yang semangatnya tinggi tetapi dari segi kemampuan rendah rendah. Mereka perlu dimotivasi dalam rangka meningkatkan kemampuannya demi kesuksesan dari proses yang diembankan kepadanya.

3. Bawahan yang memiliki potensi tinggi tetapi kemauan rendah, cara memotivasinya adalah dengan banyak melibatkan mereka dalam beberapa kegiatan tambahan. Dari kegiatankegiatan ini diharapkan bisa membuatnya terbiasa untuk mau, yakin dan mantap dalam melaksanakan tugasnya. Cara ini dikenal dengan : participating.

4. Adapun bagi yang kematangan kerja dan kemauannya tinggi, maka mereka perlu didelegasikan. Cara ini dikenal dengan nama "delegating", Diharapkan, kemauan dan 
kemampuan tinggi yang dimilikinya bisa memotivasinya lebih giat lagi, bahwa atasannya lebih memberinya semacam pengakuan (recognizing) apa yang dimilikinya dan terpacu untuk senantiasa memberikan yang terbaik (Sutarto, 2011).

Berikut ini adalah hasil temuan Thomas Naptor terkait dengan faktor-faktor yang mempengaruhi tingginya semangat kerja dan hasil ini bisa dikolaborasikan dalam lingkungan pesantren yang seringkali masalah motivasi diabaikan dikarenkan menganut system "Ketatan" dan "barokah" Kyai, yaitu :

1. Pengertian dan penghargaan kepala sekolah (kyai) kepada guru (ustadz) sebagai individu.

2. Kepercayaan guru terhadap kompetensi professional kepala sekolah (Kyai).

3. Dukungan dalam mengatasi maslah-masalah disiplin siswa (santri).

4. Partisipasi guru dalam perumusan kebijakan.

5. Perlengkapan dan fasilitas yang memadai.

6. Tugas mengajar yang sesuai dengan pendidikannya.

7. Distribusi tugas ekstrakurikuler yang adil dan pantas.

8. Latihan professional (in-service-program) jaminan kerja

9. Kebijakan cuti yang layak.

10. Distribusi beban mengajar yang adil dan pantas.

11. Gaji yang sebanding dengan profesi yang membutuhkan latar belakang pendidikan yang setaraf.

\section{Tujuan Motivasi}

Pada dasarnya, motivasi merupakan suatu dorongan semangat untuk melakukan sesuatu kegiatan dalam rangka mencapai suatu tujuan. Orang yang mempunyai motivasi yang tinggi, akan berusaha mengungkapkan potensi yang dimiliki dan memanfaatkan potensinya dengan sebaik-baiknya.

Pemanfaatan potensi ini bisa berupa cara kerja yang lebih baik untuk meningkatkan efisiensi pemakaian sumberdaya manusia dan efektivitas hasil yang dicapai. Orang yang memiliki motivasi untuk berprestasi yang tinggi, akan memunculkan tingkah laku yang kreatif, inovatif. Orang yang memiliki kreatifitas dan inovasi yang tinggi maka akan memunculkan efisiensi dan efektivitas dalam pemanfaatan sumberdaya. Apabila sfisiensi dan efektivitas sudah terwujud, maka akan melahirkan produktivitas yang tinggi pula (Departemen Tenaga Kerja Daerah Jatim, n.d.).

Skema di bawah ini diharapkan bisa membantu kejelasan penjelasan di atas:
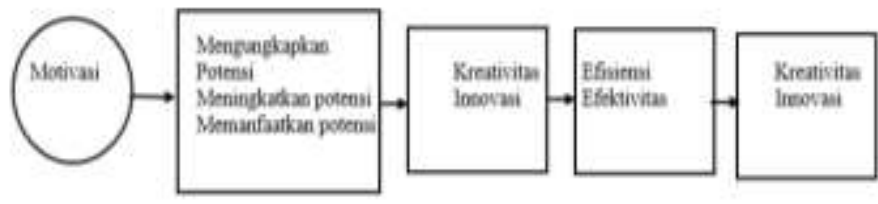

Setiap orang yang bekerja, tentu membutuhkan tenaga yang kuat. Namun kekuatan tenaga saja tidak cukup, masih memerlukan satu komponen lagi yang tidak kalah pentingnya adalah motivasi. Walaupun otaknya encer dan memiliki harta yang melimpah, tetapi tidak memiliki motivasi, maka tidak akan menghasilkan apa-apa dalam hidupnya. Oleh karena iu orang yang gagal adalah orang yang enggan untuk memperdayakan dirinya sendiri. Sedangkan kesuksesan dapat diartikan sebagai perkawinan antara potensi dan motivasi (Rahim, Abdul dan Irmin, 2004).

Dengan motivasi, dapat menciptakan 
prestasi kerja yang baik, kesetiaan, tanggung jawab, bahkan dapat mempertahankan guru (ustadz) atau karyawan yang berkualitas baik untuk bekerja bersama kita.

Tujuan pemberian motivasi menurut Hasibuan (1996:97), yaitu:

1. Mendorong gairah dan semangat kerja guru dan karyawan.

2. Meningkatkan moral dan kepuasan kerja guru

3. Meningkatkan produktivitas kerja guru dan karyawan.

4. Mempertahankan loyalitas dan kestabilan guru dan karyawan di sekolah

5. Meningkatkan kedisiplinan dan menurunkan tingkat absensi guru dan karyawan

6. Mengefektifkan pengadaan guru dan karyawan

7. Menciptakan suasana dan hubungan kerja yang baik.

8. Meningkatkan kreativitas dan partisipasi guru dan karyawan

9. Meningkatkan tingkat kesejahteraan guru dan karyawan

10. Meningkatkan rasa tanggung jawab atas tugas-tugas yang diberikannya

11. Dan lain sebagainya.

Dari identifikasi Hasibuan tersebut di atas, maka dengan motivasi diharapkan guru (ustadz) dan karyawan mau bekerja keras dan antusias untuk mencapai produktivitas yang tinggi. Tentunya seorang manajer (di perusahaan) atau kepala sekolah (di sekolah, atau kyai (di pesantren), dalam pemberian motivasi diharapkan bawahan mau bekerja keras sesuai dengan harapan organisasi sehingga kebutuhan dan keinginannya dapat terpenuhi.
Bila para pekerja mengalami kegagalan, maka seorang pemimpin berhak mencari tahu apa penyebabnya. Jika ada karyawan berprestasi ternyata di bwah standar pemimpin perlu menganalisa factor penyebabnya diantaranya motivasi yang kurang atau lingkungan kerja yang buruk. Begitu juga sebaliknya, jika karyawan memiliki keterampilan rendah tetapi sikap dan perilaku kerja yang ditunjukkan cukup baik sehingga organisasi patut memberikan pelatihanpelatihan. Strategi motivasi tepat guna jika ada karyawan memiliki keterampilan tetapi tidak mempunyai kenginan padahal mereka memiliki bakat.

Selain itu, sifat individual dari motivasi menuntut para pemimpin untuk mengambil pendekatan tidak langsung, menciptakan motivasi melalui suasana organisasi yang mendorong para karyawan untuk lebih produktif. Suasana ini tercipta dengan membuat sistem-sistem imbalan dan hukuman, menegakkan standar, peraturan, kebijakan yang ketat, dan pemeliharaan komunikasi. Gaya pemimpin juga memberikan andil dalam menciptakan suasana motivasi, terutama bila gaya tersebut mendorong rasa saling percaya.

\section{KESIMPULAN}

Motivasi sangat komplek mulai mempertahankan kegaiatan tingkat rendah yang dilakukan untuk mencapai tujuan pribadi. Beberapa teori yang sangat terkenal menjelaskan motivasi kerja yang konsisten dengan model umum, motivasi yang dikembangkan oleh Maslow yang pertama teori hierarki, menjelaskan lima tingkat hierarki kebutuhan (fisiologis, keamanan, sosial, penghargaan dan kebutuhan aktualisasi diri). Dengan kebutuhan tingkat yang lebih tinggi diaktifkan sebagai tingkat tinggi sebagai tingkat kebutuhan kepuasan. Teori 
Maslow ini telah mendapat pengakuan yang meluas, terutama diantara praktik-praktik yang dilakukan para pemimpin. Yang kedua teorinya Herzberg, hanya mengakui dua faktor dalam pekerjaan yaitu motivasi-pekerja dan kerapian.

Motivasi bisa dimaknai sebagai dorongan untuk melakukan sesuatu, dorongan itu bisa datang baik dari dalam (motivasi internal) atau dari luar (motivasi eksternal). Dalam realitanya, dua jenis motivasi ini hanya bisa dibedakan namun sulit bahkan tidak bisa dipisahkan. Motivasi merupakan unsur penting dalam setiap organisasi untuk meningkatkan SDM nya. Adapun langkah-langkah motivasi bisa melalui orientasi, supervise, partisipasi, komunikasi, cross motivation dan lain-lain.

Terkait dengan peningkatan motivasi ini, kematangan kerja (ability) dan kematangan psikologis (kemauan dan keyakinan) harus dipertimbangkan. Selanjutnya, pertimbangan akan hirarki kebutuhan manusia diharapkan bisa menjadi pertimbangan lain dalam memotivasi staf, guru (ustadz) atau karyawan.

\section{DAFTAR PUSTAKA}

Carnegie, D. (1979). Cara Mencari Kawan dan Mempengarubi Orang Lain. Jakarta: Gunung Jati.

Departemen Tenaga Kerja Daerah Jatim. (n.d.). Pengembanan Motivasi Berpresasi.

Galloway. (1985). No Title. Internasional.

Handoko, H. (1987). Manajemen Personalia dan Sumber Daya Manusia. Yogyakarta: BPFE.

Hanson. (n.d.). Educational Administration and Organizational Behavior.

Maslow, A. (1994). motivasi dan kepribadian. Jakarta: Kedokteran EGC.

Rahim, Abdul dan Irmin, S. (2004). Rasa Kecewa Biang Hancurnya Motivasi Kerja. Jakarta: Seyma Media.

Robbins, S. P. (2001). Perilaku Organisasi (1st ed.). Jakarta: PT. Prehallindo.

S.P Hasibuan. (2001). Manajemen Sumber Daya Manusia. Jakarta: Bumi Aksara.
S.P Hasibuan. (2003). No TitleOrganisasi dan Motivasi. Jakarta: Bumi Aksara.

Sutarto. (2011). No Title. Internasional.

Widjaja, A, W. (1986). Peranan Motivasi dalam Kepemimpinan. Jakarta: Akademik Pressindo.

Zainun. (2003). Manajemen dan Motivasi. Jakarta: Balai Aksara. 